\title{
Hubungan KEK dengan Anemia Gravidarum pada Ibu Riwayat BBLR
}

\author{
Arie Alfina Mahmudian ${ }^{1}$,Dian Aby Restanty ${ }^{2}$, Sugijati $^{3}$ \\ ${ }^{1)}$ Program Studi Kebidanan Jember, Politeknik Kesehatan Kemenkes Malang, alfinaarie@gmail.com \\ 2) Program Studi Kebidanan Jember, Politeknik Kesehatan Kemenkes Malang, dianabyrestanty2017@gmail.com \\ 3) Program Studi Kebidanan Jember, Politeknik Kesehatan Kemenkes Malang, sugiatisst@ gmail.com
}

\begin{abstract}
ABSTRAK
KEK (Kekurangan Energi Kronis) merupakan kondisi ibu menderita kekurangan kalori dan protein (malnutrisi) berlangsung menahun (kronis) beresiko menyebabkan komplikasi pada ibu salah satunya yaitu anemia gravidarum. Anemia dalam kehamilan adalah menurunnya kadar HB, sehingga kapasitas daya angkut oksigen untuk kebutuhan organ vital pada ibu dan janin berkurang. Tujuan penelitian ini mengetahui hubungan KEK dengan anemia gravidarum pada ibu riwayat BBLR. Desain penelitian analitik korelasi pendekatan case control study, dengan populasi sebanyak $68 \mathrm{ibu}$ riwayat BBLR, menggunakan teknik simple random sampling, sampel dihitung menggunakan rumus Slovin didapatkan jumlah 58 ibu riwayat BBLR yang memenuhi kriteria inklusi. Instrumen penelitian menggunakan lembar observasi melihat data sekunder kohort ibu hamil, analisa data menggunakan uji chi square didapatkan nilai $p$ value sebesar 0,001 artinya p<0,05 menunjukkan adanya hubungan KEK dengan anemia gravidarum pada ibu riwayat BBLR dengan keeratan hubungannya adalah cukup. Untuk nilai Koefisien Kontingensi $(K K)$ pada variabel KEK adalah sebesar 0,39 yang artinya keeratan hubungan KEK dengan anemia gravidarum adalah cukup. Nilai Odds Rasio (OR) pada variabel KEK sebesar 6,9 yang artinya ibu hamil yang status gizi KEK berisiko 6,9 kali lebih besar terjadi anemia selama kehamilan dibandingkan dengan ibu yang tidak KEK.Berdasarkan hasil penelitian tersebut, didapatkan bahwa kondisi ibu hamil dengan kebutuhan gizi yang kurang memiliki risiko lebih besar terjadi anemia selama kehamilan dan berisiko melahirkan Bayi Berat Lahir Rendah. Peneliti menyarankan untuk memberikan penyuluhan kepada wanita usia remaja, wanita usia subur dan khususnya ibu hamil sehingga bisa lebih menambah informasi tentang pentingnya status gizi pada ibu hamil, bahaya akibat anemia selama kehamilan dan juga pentingnya mengkonsumsi tablet tambah darah selama kehamilan. Sehingga diharapkan bisa mengurangi terjadinya kasus ibu hamil anemia dan BBLR.
\end{abstract}

Kata Kunci : KEK, Anemia gravidarum, BBLR

\begin{abstract}
KEK (Chronic Energy Deficiency) is a condition of the mother suffering from lack of calories and protein (malnutrition) that lasts chronic (chronic) at risk of causing complications in the mother one of which is anemia gravidarum. Anemia in pregnancy is a decrease in Hb levels, so that the carrying capacity of oxygen for the needs of vital organs in the mother and fetus is reduced. The purpose of this study is to determine the relationship of KEK with anemia gravidarum in mothers with low birth weigth history. The correlation analytic research design is a case control study approach, the population is 68 mothers with low birth weight history, using simple random sampling technique, the sample is calculated using Slovin formula, the number of 58 low birth weight history mothers fulfills the inclusion criteria. The research instrument used observation sheets to look at secondary data on cohorts of pregnant women, data analysis using the chi square test obtained a $p$ value of 0,001 means that $p<0.05$ indicates the relationship of KEK with anemia gravidarum in women with low birth weight history with a close relationship is sufficient. The value of the Contingency Coefficient in the Chronic Energy Deficiency variable is 0.39, which means that the relationship between KEK and anemia gravidarum is sufficient. The Odds Ratio (OR) value in the Chronic Energy Deficiency variable is 6.9, which means that pregnant women with nutritional status of Chronic Energy Deficiency have a 6.9 times greater risk of anemia during pregnancy than those who are not. Inadequate nutritional needs have a greater risk of anemia during pregnancy and the risk of giving birth to Low Birth Weight Babies. Researchers suggest providing counseling to women of adolescence, women of childbearing age and especially pregnant women so that they can add more information about the importance of nutritional status in pregnant women, the dangers of anemia during pregnancy and also the importance of consuming blood booster tablets during pregnancy. So that it is expected to reduce the incidence of anemia pregnant women case and low birth weight history.
\end{abstract}

Keywords : Chronic Energy Deficiency, Anemia gravidarum, Low birth weight

* Korespondensi Author: Dian Aby Restanty, Program Studi Kebidanan Jember, Politeknik Kesehatan Kemenkes Malang, Kampus 1 Jember Polkesma, dianabyrestanty2017@gmail.com,081234533997 


\section{PENDAHULUAN}

Indikator keberhasilan dalam pembangunan bidang kesehatan adalah Angka kematian Ibu (AKI) dan Angka Kematian Bayi (AKB). Sebesar 45\% kematian anak di Indonesia terjadi pada masa neonatal atau bulan pertama kehidupan. ${ }^{1}$

Tahun 2018 ibu hamil KEK dan ibu hamil anemia di Kabupaten Jember mengalami peningkatan sebesar $1,58 \%$ dan $0,93 \%$. Hal ini menyebabkan kejadian BBLR juga meningkat. Puskesmas Sukowono merupakan penyumbang BBLR tertinggi pada tahun 2018 yakni sebesar 68 kasus dari 1143 total kasus di Kabupaten Jember. Angka kejadian KEK tahun 2018 di Puskesmas Sukowono menduduki peringkat kedua sebesar 184 kasus. Angka kejadian anemianya menduduki peringkat ke-empat sebesar 275 kasus.

Ibu hamil dengan anemia dapat mengalami masalah potensial yang membahayakan. Anemia mempengaruhi turunnya kemampuan fisik karena tubuh tidak mendapat pasokan $\mathrm{O}_{2}$ yang seharusnya. Pada ibu hamil, anemia meningkatkan terjadinya komplikasi pada kehamilan dan persalinan, risiko kematian maternal, angka prematuritas, BBLR, dan angka kematian perinatal. Di samping itu perdarahan antepartum dan postpartum lebih sering dijumpai pada wanita yang anemia dan lebih sering berakibat fatal, sebab wanita yang anemia tidak dapat mentolelir kehilangan darah. ${ }^{2}$

Salah satu upaya pemerintah menurunkan kejadian anemia selama kehamilan adalah dengan suplementasi tablet tambah darah sebanyak 1 tablet setiap hari berturut-turut selama 90 hari selama masa kehamilan. ${ }^{3}$ Upaya pencegahan anemia selain pada ibu hamil, juga dilakukan pencegahan pada remaja putri dan WUS untuk mengurangi resiko terjadinya anemia saat hamil. Upaya pemerintah untuk mengatasi masalah ibu hamil KEK dengan cara Pemberian Makanan Tambahan pada ibu hamil KEK (PMT bumil KEK). Upaya tersebut difokuskan pada kegiatan promosi dan pencegahan yaitu peningkatan konsumsi makanan kaya zat besi, makanan dengan gizi seimbang, suplementasi Tablet tambah darah, peningkatan fortifikasi bahan pangan dengan zat besi dan asam folat, serta pengobatan penyakit penyerta.

Begitu besarnya dampak yang bisa ditimbulkan akibat kejadian anemia gravidarum sehingga berisiko tingginya angka kejadian BBLR, maka peneliti ingin mengetahui bagaimana hubungan KEK dengan anemia gravidarum pada ibu riwayat BBLR di wilayah kerja Puskesmas Sukowono sehingga hasil dari penelitian ini diharapkan dapat membantu institusi pelayanan publik dalam menurunkan kejadian anemia.

\section{METODOLOGI}

Pada penelitian ini menggunakan desain penelitian analitik korelasi dengan pendekatan case control study. Penelitian ini mengkorelasikan antara faktor risiko yaitu KEK (variabel independen) dengan anemia gravidarum yang merupakan faktor efek (variabel dependen) pada ibu riwayat BBLR. Pengumpulan data pada penelitian ini dengan menggunakan lembar observasi. Populasinya adalah semua ibu yang memiliki riwayat bayi BBLR yang melahirkan di Wilayah kerja Puskesmas Sukowono pada bulan Januari sampai Desember tahun 2018 yaitu 68 ibu riwayat BBLR.

Sampel dihitung dengan menggunakan rumus Slovin : $\quad n=\frac{N}{1+N e^{2}}$

$$
n=\frac{68}{1+68(0,05)^{2}}=58
$$

didapatkan hasil sampel yaitu 58 ibu dengan riwayat BBLR. Penelitian ini menggunakan teknik simple random sampling. Dengan kriteria inklusi yaitu ibu dengan riwayat Bayi Berat Lahir Rendah (BBLR) yang lahir di Wilayah kerja Puskesmas Sukowono Kabupaten Jember pada bulan Januari sampai Desember tahun 2018, ibu yang memiliki Bayi gemelli BBLR yang lahir di Wilayah kerja Puskesmas Sukowono Kabupaten Jember pada bulan Januari sampai Desember tahun 2018. Alat ukur yang digunakan pada penelitian ini adalah menggunakan lembar observasi. Data berbentuk 
nominal sehingga uji statistik menggunakan Chi Square dan dilanjutkan dengan Koefisien Kontingensi (KK) untuk mengetahui besar hubungan.

\section{HASIL DAN PEMBAHASAN}

Berdasarkan tabel di bawah ini, karakteristik responden yang diambil memiliki usia paling banyak risiko rendah sebesar 57\%, tingkat pendidikan yang paling banyak adalah tingkat pendidikan rendah yakni sebesar 55\%, tidak bekerja yakni sebesar $81 \%$, dan memiliki paritas rendah sebesar $91 \%$.

Tabel 1.Karakteristik responden berdasarkan usia, tingkat pendidikan, pekerjaan dan paritas.

\begin{tabular}{llc}
\hline $\begin{array}{l}\text { Karakteristik } \\
\text { Responden }\end{array}$ & Jumlah & \% \\
\hline Usia & & \\
\hline $\begin{array}{l}\text { Risiko tinggi (<20th dan } \\
>35)\end{array}$ & 25 & 43 \\
\hline Risiko rendah (20-35 th) & 33 & 57 \\
\hline Tingkat Pendidikan & & \\
\hline $\begin{array}{l}\text { Pendidikan rendah } \\
\text { (SD,SMP) }\end{array}$ & 32 & 55 \\
\hline $\begin{array}{l}\text { Pendidikan tinggi (SMA, } \\
\text { PT) }\end{array}$ & 26 & 45 \\
\hline Pekerjaan & & \\
\hline Tidak bekerja & 47 & 81 \\
\hline Bekerja & 11 & 19 \\
\hline Paritas & & \\
\hline $\begin{array}{l}\text { Paritas rendah } \\
(1-3)\end{array}$ & 53 & 91 \\
\hline Paritas tinggi (>3) & 5 & 9 \\
\hline
\end{tabular}

Tabel 2. Distribusi frekuensi berdasarkan Status KEK pada ibu riwayat BBLR

\begin{tabular}{|c|c|c|}
\hline Status KEK & Frekuensi & $\begin{array}{l}\text { Presentase } \\
(\%)\end{array}$ \\
\hline Tidak KEK & 31 & 53,4 \\
\hline KEK & 27 & 46,6 \\
\hline Total & 58 & 100 \\
\hline
\end{tabular}

Pada penelitian ini menunjukkan bahwa jumlah ibu riwayat BBLR yang tidak KEK selama masa kehamilan lebih besar yakni 53,4\% dibandingkan dengan yang KEK. Namun demikian, untuk jumlah ibu riwayat BBLR yang mengalami KEK selama masa kehamilannya sebanyak $46,6 \%$ bisa dikatakan bahwa jumlah ini juga tidak sedikit, sehingga menurut peneliti hal ini juga tetap bisa dipandang sebagai suatu permasalahan.

Kekurangan Energi Kronik (KEK) adalah salah satu keadaan dimana ibu menderita kekurangan kalori dan protein (mal nutrisi) yang berlangsung menahun (kronis) yang mengakibatkan timbulnya gangguan kesehatan pada ibu hamil. ${ }^{4}$ Adapun penyebab terjadinya KEK antara lain masukan makanan yang tidak adekuat, gangguan pencernaan atau absorpsi protein dan kalori yang tidak adekuat karena kebutuhan gizi selama hamil meningkat untuk memenuhi gizi ibu dan janin yang dikandungnya. ${ }^{5}$

Tabel 3. Distribusi frekuensi berdasarkan Status anemia gravidarum pada ibu riwayat BBLR

\begin{tabular}{ccc}
\hline Status anemia & Frekuensi & $\begin{array}{c}\text { Presentase } \\
(\%)\end{array}$ \\
\hline Tidak anemia & 24 & 41,4 \\
Anemia & 34 & 58,6 \\
\hline Total & 58 & 100 \\
\hline
\end{tabular}

Pada penelitian ini menunjukkan bahwa ibu riwayat BBLR yang mengalami anemia selama masa kehamilan adalah sebesar 58,6\%. Hal ini menunjukkan bahwa sebagian besar ibu riwayat BBLR mengalami anemia selama masa kehamilannnya.

Anemia dalam kehamilan merupakan suatu kondisi adanya penurunan sel darah merah atau menurunnya kadar $\mathrm{Hb}$, sehingga kapasitas daya angkut oksigen untuk kebutuhan organorgan vital pada ibu dan janin menjadi berkurang. ${ }^{6}$ Anemia gravidarum atau yang biasa disebut dengan anemia defisiensi besi disebabkan oleh beberapa faktor diantaranya adalah faktor usia, tingkat pendidikan dan pekerjaan. $^{7}$

Kehamilan usia $<20$ tahun secara biologis, emosi manusia belum optimal dan cenderung labil serta mentalnya belum matang. Hal ini bisa 
berakibat pada kurangnya perhatian terhadap pemenuhan kebutuhan zat gizi selama kehamilannya. Pada usia $<20$ tahun, kondisi tubuh wanita belum siap menerima kehamilan karena masih dalam masa pertumbuhan, oleh karena itu, zat gizi masih dibutuhkan oleh ibu hamil untuk masa pertumbuhannya dan gizi untuk kehamilan sendiri menjadi berkurang sehingga rentan terjadi anemia. Usia ibu hamil >35 tahun juga terkait dengan kemunduran dan penurunan daya tahan tubuh serta kondisi biologis ibu hamil yang mulai mengalami penurunan sehingga membuat ibu tidak begitu memperhatikan nutrisi selama masa kehamilannya. Sehingga hal ini juga bisa membuat ibu dengan usia $>35$ tahun rentan mengalami anemia.

Selain dari faktor usia, faktor lain yang juga bisa mempengaruhi anemia adalah dari tingkat pendidikan. Hal tersebut selaras dengan penelitian yang dilakukan oleh Ristica bahwa terdapat $68,5 \%$ ibu hamil yang terdiagnosa anemia gravidarum memiliki pendidikan yang tergolong rendah Anemia banyak terjadi pada kelompok penduduk dengan tingkat pendidikan rendah. Kelompok ini umumnya kurang memahami akibat dari anemia, kurang mempunyai akses informasi anemia dan penanggulangannnya, kurang dapat memilih bahan makanan bergizi yang mengandung zat besi lebih tinggi, sehingga pada penduduk yang tingkat pendidikannya lebih rendah cenderung terkena anemia daripada yang berpendidikan tinggi. $^{8}$

Pekerjaan adalah aktifitas yang harus dilakukan terutama untuk menunjang kehidupannya dan juga keluarga. Selain menyita waktu, bekerja memberi pengalaman dan pengetahuan, baik langsung maupun tidak karena adanya tukar menukar informasi antar teman ditempat kerja. ${ }^{9}$ Pada ibu hamil yang tidak bekerja tentunya akan lebih sedikit memperoleh informasi yang salah satunya adalah informasi tentang gizi ibu hamil. Selain itu, ibu hamil yang kesehariannya mempunyai kewajiban untuk mengerjakan pekerjaan rumah tangga yang tidak ringan dan cukup menguras tenaga, cenderung mengalami anemia selama kehamilan dikarenakan letih dan kurang istirahat. Hal ini diperparah lagi jika ibu hamil tersebut memiliki anak, karena ibu akan lebih terfokus pada anak dan keluarga sehingga tidak memperhatikan gizi makanannya.

Tabel 4. Distribusi responden berdasarkan Hubungan KEK dengan anemia gravidarum di Wilayah kerja Puskesmas Sukowono

\begin{tabular}{|c|c|c|c|c|c|c|c|}
\hline \multirow{3}{*}{$\begin{array}{c}\text { Status } \\
\text { KEK }\end{array}$} & \multicolumn{4}{|c|}{ Gravidarum } & \multirow{3}{*}{$\begin{array}{c}p- \\
\text { value }\end{array}$} & \multirow{3}{*}{ OR } & \multirow{3}{*}{ KK } \\
\hline & \multicolumn{2}{|c|}{ Tidak } & \multicolumn{2}{|c|}{$\mathrm{Ya}$} & & & \\
\hline & $\mathrm{n}$ & $\%$ & $\mathrm{n}$ & $\%$ & & & \\
\hline Tidak & 19 & 79,1 & 12 & 35,3 & \multirow{4}{*}{0,001} & \multirow{4}{*}{6,9} & \multirow{4}{*}{0,39} \\
\hline KEK & & & & & & & \\
\hline KEK & 5 & 20,9 & 22 & 64,7 & & & \\
\hline Total & 24 & 100 & 34 & 100 & & & \\
\hline
\end{tabular}

Berdasarkan tabel 4 diperoleh hasil bahwa nilai $p$ value sebesar 0,001 artinya KEK berhubungan dengan status anemia gravidarum pada ibu riwayat BBLR di wilayah kerja Puskesmas Sukowono Kabupaten Jember. Untuk nilai Koefisien Kontingensi (KK) pada variabel KEK adalah sebesar 0,39 yang artinya keeratan hubungan KEK dengan anemia gravidarum adalah cukup. Nilai Odds Rasio (OR) pada variabel KEK sebesar 6,9 yang artinya ibu hamil yang status gizi KEK beresiko 6,9 kali lebih besar terjadi anemia selama kehamilan dibandingkan dengan ibu yang tidak KEK.

Hasil penelitian ini sesuai dengan teori yang dijelaskan oleh Rahmaniar bahwa salah satu faktor yang mempengaruhi kejadian anemia pada ibu hamil adalah malnutrisi atau Kekurangan Energi Kronik (KEK). ${ }^{10}$ Dari hasil penelitian ini didapatkan bahwa ibu hamil KEK lebih banyak mengalami anemia selama kehamilan yakni sebesar $64,7 \%$ sehingga dapat ditarik kesimpulan bahwa KEK mempengaruhi kejadian anemia selama kehamilan pada ibu riwayat BBLR.

Nutrisi selama kehamilan adalah salah satu faktor penting dalam pembentukan janin. Pola makan yang baik akan cukup menyediakan gizi yang dibutuhkan untuk kesehatan selama kehamilan. Kebutuhan gizi ibu hamil yaitu zat 
gizi (baik mikro maupun makro) dibutuhkan oleh seorang ibu hamil baik pada TM 1, TM II, dan TM III untuk memenuhi kebutuhan sehari hari agar janin yang dikandungnya dapat tumbuh dengan baik. Seorang ibu yang tidak memiliki ataupun kekurangan gizi selama awal kehamilan maka akan beresiko terjadinya anemia pada ibu dan juga beresiko bayi yang dikandungnya mengalami Berat Bayi Lahir Rendah (BBLR). ${ }^{11}$

Dari tinjauan teori tersebut dapat diketahui bahwa Status gizi dan kesehatan ibu pada masa sebelum hamil dan saat kehamilan merupakan periode sangat penting. Ibu hamil yang mengalami KEK beresiko mengalami anemia, hal ini bisa terjadi karena KEK menggambarkan status gizi ibu hamil yang kurang sehingga pemenuhan nutrisi belum cukup terpenuhi. Pada ibu hamil dengan KEK akan terjadi pola konsumsi dan absorbsi makanan yang tidak seimbang, sedangkan ibu hamil harus memiliki gizi yang cukup karena gizi yang didapat akan digunakan untuk memenuhi kebutuhan gizi ibu dan juga untuk janin yang dikandungnya. Kebutuhan gizi pada ibu hamil yang terpenuhi dalam makanan seharihari akan berpengaruh pada pertumbuhan dan perkembangan bayi. Namun tidak hanya itu, pemenuhan kebutuhan gizi yang seimbang baik makronutrien maupun mikronutrien juga asupan nutrisi yang mengandung zat besi didalam makanan sangat dibutuhkan, karena akan berdampak pada kesehatan ibu selama hamil. Kondisi ibu hamil yang kebutuhan gizi nya kurang, akan memiliki risiko lebih besar untuk terjadi anemia selama kehamilan dan memiliki risiko untuk melahirkan bayi dengan berat lahir rendah.

Kondisi ibu yang memiliki gizi sudah terpenuhi sebelum ataupun pada awal kehamilannya, sehingga ibu tidak mengalami (KEK), cenderung memiliki risiko lebih kecil untuk terjadi anemia selama kehamilan. Hal ini bisa saja terjadi, dikarenakan ibu hamil yang tidak KEK pasokan nutrisi dan zat besi sebelum hamil ataupun pada awal kehamilan sudah cukup untuk memenuhi kebutuhan status gizi nya. Namun, selama masa kehamilan kebutuhan gizi tidak cukup hanya digunakan untuk memenuhi kebutuhan ibu saja, tetapi juga kebutuhan bagi janin, sehingga disamping zat besi yang didapat dari makanan hewani dan juga nabati, kepatuhan ibu dalam mengkonsumsi tablet Fe juga sangat penting untuk mencegah terjadinya anemia pada saat hamil. Untuk itu, pemerintah juga memberikan kebijakan pemberian tablet tambah darah $(\mathrm{Fe})$ minimal 90 tablet selama masa kehamilan untuk membantu mencegah terjadinya anemia selama masa kehamilan.

\section{SIMPULAN DAN SARAN}

Berdasarkan hasil penelitian ini dapat disimpulkan bahwa : KEK dengan anemia gravidarum pada ibu riwayat BBLR memiliki hubungan keeratan yang cukup dan ibu dengan KEK berisiko 6,9 kali lebih besar mengalami anemia selama kehamilan. Kebutuhan gizi pada ibu hamil akan berpengaruh pada pertumbuhan dan perkembangan janin. Selain itu kepatuhan konsumsi $\mathrm{Fe}$ juga sangat penting untuk mencegah anemia saat hamil.

Saran untuk peneliti selanjutnya ialah perlu adanya penelitian kualitatif untuk mengetahui secara mendalam mengenai faktor yang mempengaruhi KEK dan juga anemia gravidarum pada ibu riwayat BBLR.

\section{UCAPAN TERIMA KASIH}

Peneliti mengucapkan terima kasih kepada semua pihak yang telah membantu terselesaikannya penelitian ini, baik pada saat proses permohonan ijin penelitian dan saat pengambilan data penelitian.

\section{REFERENSI}

1. Profil Kesehatan Indonesia 2018.; 2018.

2. Hikmah N, Puspita, Dian Ayu. Risiko F, Berpengaruh Y, et al. J URNAL EDUHEALTH. 2015;5(2).

3. Susiloningtyas I. PEMBERIAN ZAT BESI (Fe) DALAM KEHAMILAN Is Susiloningtyas.

4. Helena. Gambaran pengetahuan gizi ibu hamil trimester pertama dan pola makan dalam pemenuhan gizi. www.repository.usu.ac.id. Published online 2013.

5. Arisman. Gizi Dalam Daur Kehidupan. EGC; 2009. 
6. Astutik, Reni. Yuliana D. Anemia Dalam Kehamilan. Pustaka Abadi; 2018.

7. Nguyen, P.H., I.G. Cassanova, H. Nguyen, H. Pham, TV. Truong, S. Nguyen, R. Martorell UR. Multicausal Etiology of Anemia Among Women of Reproductive Age in Vietnam. Eur J Clin Nutr. Published online 2014:1-7.

8. Ristica OD. Faktor Risiko Kejadian Anemia pada Ibu Hamil Risk Factors Related to Anemia in Pregnant Women. 2013;2(7):78-82.

9. Notoatmodjo S. Promosi Kesehatan Dan Ilmu Perilaku. Rineka Cipta; 2010.

10. Kejadian D, Pada A, Hamil IBU. Pengaruh kekurangan energi kronis (kek) dengan kejadian anemia pada ibu hamil. Published online 2009:167-172.

11. Simbolon D. Pencegahan Dan Penanggulangan Kurang Energi Kronik (KEK) Dan Anemia Pada Ibu Hamil. Deepublish; 2018. 